\title{
Effect of Diversification on Financial Performance of Commercial Banks in Kenya
}

\author{
John Gichia Ndungu ${ }^{1}$ \\ Prof. Willy Muturi \\ ${ }^{1,2}$ Jomo Kenyatta University of Agriculture and Technology (JKUAT), Kenya
}

\begin{abstract}
\end{abstract}
Diversification plays a vital role in risk management and consequently financial performance of commercial banks. Diversification mitigates systemic risk facing a commercial bank and thus reduces the probability of bank failure. In Kenya, commercial banks have been diversifying their business by increasingly offering new services such as mobile banking, agency banking, bank-assurance, faceless banking and integrating microfinance in their banking system. Diversification by the commercial banks is premised on the need to enhance financial performance. This has mainly emanated from banking industry having undergone numerous regulations regimes which over the years have affected financial performance of these entities. Empirical literature shows that diversification may not always lead to higher financial performance due to increased overheads and exhausted economies of scale. The study sought to determine the effect of diversification on financial performance of commercial banks in Kenya. The specific objectives of the study were to determine the effect of income diversification on financial performance of commercial banks in Kenya, to examine the effect of geographical diversification on financial performance of commercial banks in Kenya and to examine the effect of product diversification on financial performance of commercial banks in Kenya. Secondary data used by the study was collected for five years period (2013-2017 on annual basis). All the commercial banks were studied. Data was analysed using descriptive and inferential statistics and presented in tables and figures. The study found that Income Source Diversification and Geographical Diversification had a positive effect on the financial performance of the commercial banks while the Product Diversification had a negative impact the financial performance the commercial banks. The findings from the OLS regression analysis revealed that the diversification components studied namely product diversification, geographical diversification and income diversification explain up to $13.3 \%$ of the variations in return on assets $\left(R^{2}=0.133\right)$ and $18.7 \%$ of the variations in return on equity $\left(R^{2}=0.187\right)$. The study concluded that financial performance of the commercial banks in Kenya can be accounted for by the diversification strategies that have been implemented. It was further concluded that increased formulation and implementation of additional diversification strategies resulted in significant improvement in the financial performance of the commercial banks. The study recommended that managers at the commercial banks to make formulation and implementation of diversifications as a key organizational priority. Before the adoption of any particular diversification, the management of the commercial banks are econcouraged to first determine the suitability of that particular diversification strategies based on the organization structure, culture and policies and the overall intended outcomes. The study recommends that the government and other regulatory bodies to create favourable policies on the implementation of diversifications in commercial banks. This will ensure that there is effectiveness, efficiency as well as consistency in the use and adoption of diversifications by not only the banks but also other organizations in different sectors.

Key Words: Income Diversification, Geographical Diversification, Product Diversification, Diversification, Financial Performance of Commercial Banks in Kenya

DOI: $10.35942 /$ ijcab.v3iV.67 


\section{Cite this Article:}

Ndungu, J., \& Muturi, W. (2019). Effect of Diversification on Financial Performance of Commercial Banks in Kenya. International Journal of Current Aspects, 3(V), 267-285. https://doi.org/10.35942/ijcab.v3iV.67

\section{Introduction}

The conventional knowledge in the banking industry is that diversification improves financial performance by reducing volatility in commercial banks financial returns (Damankah, AnkuTsede \& Abubakar, 2015). Further, supporting the conventional view, Turkmen and Yigit (2012) indicated that diversification influence commercial banks financial performance since losses from one exposure source can always be compensated by gains from the other segments. Theoretical knowledge support the role of diversification in improving financial performance of commercial banks. Diversification is a concept that involves firm into new lines of activities either by the process of internal expansion or by acquisition, or firm having more than one product and business activities in more than one industry (Kipleting, 2016). It is a form of growth marketing strategy for a company which seeks to increase profitability through greater sales volume obtained from new products and new markets. A diversification strategy stands apart from the other three strategies such as merger and acquisition, internal start up, Joint Venture and requires a company to acquire new skills, new techniques and new facilities. Therefore, diversification is meant to be the riskiest of other strategies to pursue (Makokha, 2016).

The main types of diversification entail income diversification, product diversification and geographical diversification. Product diversification is defined as the extent to which a firm's different lines of business are linked by a common skill, market, purpose, or resource (Luo, 2002). Income source diversification refers to commercial banks shifting their income sources into non intermediation income generating activities as opposed to the traditional intermediation income generating activities (Stiroh, 2004). While geographical diversification entails the increase in number of activities a firm undertakes in different regions and sectors. Diversification play a vital role in risk management and consequently financial performance of commercial banks. This is based on the assumption that better diversification removes the systemic risk of a particular sector and reduces the probability of bank failure. In this context, banks with bigger size, in terms of total assets and branch network, are expected to be better diversified than smaller banks (Afzal \& Mirza, 2012). Empirical findings indicate that financial diversification may not always lead to higher financial performance (Alaaeddin, 2017; Mochabo, 2017).

In Kenya, over the years, diversification has been viewed as important in improving commercial banks financial performance. This has mainly emanated from banking industry having undergone numerous regulations regimes which over the years have affected financial performance of these entities. Most recent regime change in the banking sector is the interest rate capping that came to effect in 2016. Interest rate capping was implemented following concerns raised by the public regarding the high cost of credit in Kenya, which was viewed as a hindrance to credit access by a large segment of the population. Implementation of the law, was therefore, expected to lower the cost of credit and increase access to credit. This had huge effect on bank interest income with banks considering diversification to complement interest income (Central Bank of Kenya, 2018). This position is however not supported by empirical evidence where studies have found contradicting findings. The banking business around the world plays a major role in the business of financial intermediation and has grown over the years, resulting in the diversity and complexity of its operations. Based on this development, banks have advanced from what used to be their normal line of business, which is, mobilizing 
deposits and making loans, to other financial non-interest earning intermediation services such as the provision of financial guarantees, derivative arrangements and the like. These activities are widespread in developed countries and have been widely reported in academic literature (Damankah, et al, 2015).

Changing trends globally and customers' expectations are directing banks to search the new ways of income generation. Banks are now moving towards diversification of their revenues to reduce risk of their portfolios and to increase the profitability. In effort of diversifying the income generation activities, banks are indulging in non- interest income generation activities by reducing their reliance on traditional banking activities. Diversification of income generating activities (either interest based or non-interest based) can enhance the profitability by reducing overall risk involved in banking operation (Ismail, 2015). Conventional global banking industry wisdom predicts that combining different types of activities non-interest earning and interest-earning assets- and rebalancing bank income away from interest income and toward non-interest activities may increase return and diversify risks, therefore boosting performance. Empiric's studies tend, however, to contradict these conventional industry beliefs (Saoussen \& Plihon, 2011). Majorly, studies done in US financial institutions have not been able to relate financial diversification. Most studies conclude that the costs of diversification outweigh the benefits (Stiroh 2004; Stiroh and Rumble, 2006; Laeven and Levine, 2007; Goddard et al., 2008). Fewer studies deal with European banks. Among them, Mercieca et al. (2007) explores the economic impact of diversification on average profitability by calculating the effect of an increase in the non-interest share on a sample of 755 small European banks for the period 1997-2003. The study found a negative net effect for average profitability and a corresponding positive effect on volatility are detected. Hayden (2007) investigated German banks and found that diversification tends to be associated with reductions in bank returns, even after controlling for risk. Only in a few cases (high-risk banks and industrial diversification) did they reach statistically significant positive relationships between diversification and bank returns.

In Ghana, Damankah, et al (2015) noted that in Ghana, financial stabilization and deregulation have had important implications on the income statements of banks. There has been a shift from net interest income to non-interest income not dependent on traditional financial intermediation. The decline in interest margins has changed the traditional role of banks and has forced them to search for new sources of revenue. Structural changes such as industry deregulation, new information technologies and financial innovation have also increased the importance of fee income (Damankah, et al, 2015). Studies have also found no relationship between diversification and business performance. Adamu et al (2011) while evaluating the impact of product diversification on financial performance of selected Nigerian construction firms found established that undiversified construction firms performed much better using various performance measures like Return on Total Assets and Profit Margin. This was attributed to mainly to lack of efficiency in the utilization of assets by highly diversified firms to generate profit (Adamu et al, 2011).

The banking industry in Kenya is developing and is characterized by intense rivalry and competition from microfinance institutions and non-bank financial institutions and frequently changing regulations (Tsuma and Gichinga, 2016). Commercial banks are also required to make many disclosures in the financial statements which imply lack of confidentiality on business strategies. Recently in 2016, the Banking Act was amended bringing about interest rate controls in Kenya. Collectively, these specific characteristics of banking industry makes it hard for the banks to achieve optimum financial returns (Central Bank of Kenya, 2016). The banking industry has been earmarked as a key pillar to the achievement of vision 2030 (a longterm strategy to achieve sustainable growth by year 2030) through increased savings, 
encouragement of Foreign Direct Investment, safeguarding the economy from external shocks as well as propelling Kenya to become a leading financial center in Eastern and Southern Africa (Republic of Kenya, 2008). In Kenya, commercial banks have been diversifying their business by increasingly offering new services such as mobile banking, agency banking, bankassurance, faceless banking and integrating microfinance in their banking system (CBK, 2014).

Diversification by the commercial banks in Kenya is premised on the need to enhance financial performance in dynamic banking industry. Central Bank (2018) argues that with increasing regulatory environment including interest rate caps, banks have been forced to diversify their income sources although the effect of this on financial performance is yet to be fully explored in literature. Few studies done in recent years have found positive effect of diversification on financial performance contrary to regional and global studies. For example, Makokha, Namusonge, and Sakwa (2016) explored the effect of portfolio diversification on commercial banks financial performance in Kenya. The findings were that portfolio diversification was positively related to changes in the financial performance of commercial banks in Kenya. Diversification in investments enabled banks to increase profits and performance in the past years. Although not in the banking industry, Ogada (2016) studied the effect of diversification on the financial performance of merged institutions and found that diversification had no significant effect on financial performance of merged institutions.

\section{Statement of the Problem}

Commercial bank industry in Kenya like elsewhere in the world is highly regulated which limits the ability of commercial banks to maximize financial performance. The introduction of interest rate capping has further reduced the amount of interest income commercial banks can generate on loans (Central Bank of Kenya, 2018). These industry dynamics have seen a number of banks collapsing including imperial bank in 2015 and Chase bank in 2016 and others reporting reduced profit levels of up to 25\% (Central Bank of Kenya, 2018; Tsuma, \& Gichinga, 2016). The conventional knowledge in the banking industry is that diversification improves financial performance by reducing volatility in commercial banks financial returns (Damankah, Anku-Tsede \& Abubakar, 2015). Turkmen and Yigit (2012) argue that financial diversification influence commercial banks financial performance since losses from one exposure source can always be compensated by gains from the other segments. This view is supported by diversification theories including portfolio theory. However, empirical evidence contradicts this view where most studies have found contradicting findings on the effect of financial diversification on financial performance.

Berger, Hasan and Zhou (2010) studied the performance of 88 Chinese banks between 1996 and 2006. The findings suggested a negative impact of diversification on bank performance in all activity areas. Ismail (2015) found positive impact of income diversification on performance of banks in Pakistan. Damankah, et al (2015) studied the income diversification and financial stability of banks in Ghana and found that diversification improved financial performance. Sigve and Lars (2017) found that increased funding diversification improved performance for banks in Norway. Kenyoru (2016) studied the effect of product diversification on financial performance of selected banks in Kericho Town. The findings indicated significant and positive relationship between product diversification and bank financial performance. Makokha et al found that portfolio diversification was positively related to changes in the financial performance of commercial banks in Kenya. Mochabo (2017) established that geographical diversification was positively and significantly correlated with financial distress. Ogada (2016) studied the effect of diversification on the financial performance of merged institutions and found that diversification had no significant effect on financial performance of merged institutions. Notably, the findings on the effect of various types of diversification on financial 
performance is not clear. Further, most of the studies have varying measurement of level of diversification in addition to using primary data which mainly obtains opinions of the respondents. It is based on this fact that this study evaluated the effect of diversification on financial performance of commercial banks in Kenya. It sought to answer the question; what is the effect of diversification on financial performance of commercial banks in Kenya?

\section{Objectives of the Study}

The general objective was to determine the effect of diversification on financial performance of commercial banks in Kenya

The specific objectives of the study were;

i. To determine the effect of income diversification on financial performance of commercial banks in Kenya

ii. To examine the effect of geographical diversification on financial performance of commercial banks in Kenya

iii. To examine the effect of product diversification on financial performance of commercial banks in Kenya

\section{Theoretical Review}

The study was guided by portfolio theory, agency theory and Winton's theory of a non-linear diversification effect. The theory provides the expected relationship between the study dependent and independent variables.

\subsection{Portfolio Theory}

Portfolio theory is associated with Markowitz (1952). The theory postulates that diversification leads to reduction in fluctuation of revenues/incomes and therefore positively impacting on financial performance of commercial banks. The theory holds that both maximum expected returns and the variations in the minimum values should exist so as to attain an efficient portfolio that is capable of reducing risks. Therefore profits may be attained by avoiding those assets that are likely to result in diminished returns or those that do not perform as well as expected. This thus leads to a scenario whereby there are options in the assets and resources to be used in accomplishing a particular task or else known as diversification (Brealey \& Myers, 2003). Commercial Banks have over the years noticed that there is a need to diversify their portfolio of offerings to remain relevant, increase their earnings and maintain their sustainability in this cut-throat competitive financial services industry. With the liberalization of the market coupled with deregulation and globalization, banks have found it increasingly difficult and costly to maintain their profitability. Jongeneel (2011) noted factors such as and evolved e-commerce channel and changes in consumer attitudes leading to the steady decline in interest margins on loans of Commercial Banks from the 1980s.

The importance of the theory is that it allows investors to reduce exposure to individual assets hence limiting the expected loss. Therefore, the portfolio which is efficient encompasses assets which are either risky but of high value or those that are less risky but having lower value. However, according to Eiteman,(2016), the theory makes assumption that there is an efficient financial market and there is normal distribution of the assets return. Additionally, the theory does not take into account future investment objectives which are prone to change over time (Gray, 2003). The theory's proposition to this study is that the banks may reduce the risk facing the investments by distributing the investment amounts among all those securities which give a maximum expected return. According to this theory all the various forms of diversifications employed by the commercial banks namely income diversification, aim at ensuring financial sustainability, security and minimization of financial risk. This theory therefore predicts a 
positive relationship between financial diversification and financial performance. Diversifications therefore acts as a means of increasing returns in the commercial banks while minimizing risks.

\subsection{Agency Theory}

The theory is related to Jensen and Meckling (1976). The theory suggest that diversification will not lead to improved financial performance since with diversification, small shareholders find it difficult to monitor and govern diversified corporations and thus corporate insiders will have greater latitude to extract private benefits from the diversified banks leading to adverse effects on firm financial performance. Diversification can also lead to higher risk given the adverse selection problems to the extent that existing intermediaries abandon the riskiest and least profitable customers. According to the theory, important managerial decisions should not be undertaken solely by the manager in charge, but by through a designated board. This will ensure that the strategies put in place have no personal motives behind them. The theory's assumption is that aligning both the interests of managers and stakeholders may lead to improved performance. However, though agency theory is very pragmatic and popular, it still suffers from various limitations and this has been establshed by various empirical studies conducted such as Eisenhardt (1989), Shleifer and Vishny (1997) and Daily et al., (2003).

The Agency Theory has thus faced criticism as this may not be easy in application as each party always yearns to gain the most for themselves first (Gleason, 2011). According to Cui,(2003), firms can be disciplined by the competition from the other players, which monitors the performance of the entire team and the individual person hence no occurence of agency problems in the organizations. Additionally, the theory only focuses on the principal and agent conflict, agency cost and the realignment of both the parties' interest without taking into consideration the agent's motivation, risk averseness, time preference and equitable compensation which affect the operations in the organizations (McKnight, and Weir, 2009). Agency Theory's proposition to this study is that the formulation of the diversification strategies in the banks is the sole responsibility of the managers involved. Due to the agency conflict where managers pursue personal goals as opposed to those of shareholders, agency theory predict a negative relationship unless the goals of the managers are well aligned with those of shareholders. Based on this theory, diversification strategies such as product and geographical diversifications act as way of minimization of agency risk hence ensuring aligning of interests of the managers, stakeholders and customers in maximization of share capital which translate to improved performance.

\subsection{Winton's theory of a non-linear diversification effect}

In an attempt to model a bank's choice between different diversification strategies, Winton (1999) developed a framework where he shows that the effect of a diversified loan portfolio on performance strongly depends on the level of sector risk and monitoring incentives. According to the theory, specialized bank with a loan portfolio exposed to low levels of risk will have a low probability of failure. Diversification will thus have few benefits. Moreover, in the presence of high levels of risk, diversification may increase the likelihood of bank failure; a diversified bank is exposed to more potential sector downturns, which increases the probability of failure. According to his model, benefits of diversification are in fact greatest when the investment portfolio is exposed to moderate risk levels. Winton justifies this by referring to a risk level high enough to pose a threat of failure if a bank specializes, but not so high that a downturn in one sector is severe enough to cause the failure of a diversified bank. This dynamic implies a non-linear relationship between return and diversification conditioned on the degree of risk. Winton (1999) further argues that whenever increased diversification lessens banks' ability or incentive to monitor, the chance of bank failure increases. For instance, when entering 
a new sector a bank has to gain thorough understanding and knowledge of the market to develop effective monitoring. Such sectoral knowledge takes time to acquire, and the bank will have a competitive disadvantage against incumbent banks. This is in line with the view of Mishkin et al. (2013) regarding how a specialized bank may benefit from a more efficient screening- and monitoring process due to superior industry knowledge.

The importance of Winton's theory of a non-linear diversification effect is supported empirically by various scholars such as Stiroh, (2004), De Jonghe, (2010) and Klein and Saidenberg, (2010) who established that diversified banks can benefit from leveraging managerial skills and abilities across products, gaining economies of scope by spreading fixed costs over products and stabilizing overall profits. However, according to Gambacorta, Scatigna, and Yang, (2014), the main limitation of the theory is that diversified banks can suffer from dilution of the comparative advantage of management and and increasing volatility of profits leading to reduced organizational performance. However, it is not clear from a theoretical point of view whether banks should pursue a focused or diversified strategy for their risks. The theory therefore forecasts a positive or negative effect of diversification on financial performance of commercial banks. Based on this theory, the effects will be dependent on the specific factors underlying the various commercial. The diversification strategies are theorized to have a significant positive influence on the financial performance of the commercial banks only up to a certain extent beyond which additional risks and expenses are bound to occur.

\section{Conceptual Framework}

Conceptual framework entails a diagrammatic representation of the relationship between the variables of the study (Mugenda \& Mugenda, 2008). The conceptual framework for the study is shown by Figure 1.

\section{Independent Variables}

\section{Dependent Variable}

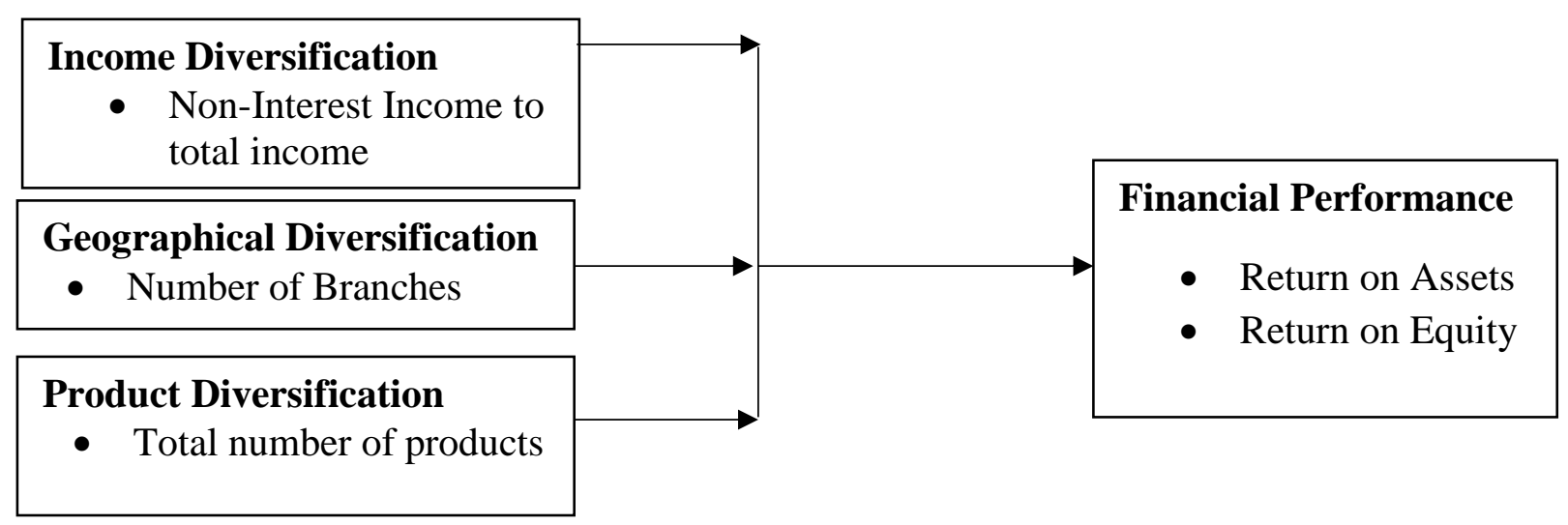

\section{Figure 1: Conceptual Framework}

\section{Empirical Literature Review}

Saoussen and Plihon (2011) studied revenue diversification in emerging market banks: implications for financial performance. The paper examined whether the observed shift into non-interest based activities improved financial performance. Using a sample of 714 banks across 14 East-Asian and Latin-American countries over the post 1997-crisis changing structure, the study found that diversification gains were more than offset by the cost of increased exposure to the non-interest income, specifically by the trading income volatility. But this diversification performance's effect is found to be no linear with risk, and significantly not uniform among banks and across business lines. An implication of these findings is that 
banking institutions can reap diversification benefits as long as they well-studied it depending on their specific characteristics, competences and risk levels, and as they choose the right niche.

Lepetit et al (2008) studied the impact of noninterest revenue on the risk structure of banks. They used a sample of 734 listed and non-listed banks in 14 European countries from the period 1996 to 2002. To capture the level of earnings diversification, they employ an income statement approach by taking proportion of net non-interest income to total operating income. The non interest income was then further classified on the basis of commission, fee and trading income. The risk variables used were based both on accounting and market data. The accounting measures comprised of standard deviation of ROA, ROE and loan loss provisions to net loans. The insolvency risk was proxy by $\mathrm{Z}$ score. The market risk measures included systematic risk, standard deviation of weekly stock returns, idiosyncratic risk and distance to default. Among income statement risk factors, they found out that banks with higher level of revenue diversification were prone to higher risks. These results remained robust for market based risk measures with risk being higher for banks where revenue diversification is driven by commission and fee income. Considering the banks size, they reported that small banks were less risky when they complement their operating income by trading activities, while larger banks were less exposed to risk if diversification is mainly in commission and fee based revenue. They concluded that counter to common intuition trading activities do not increase the risk profile of a bank, rather for banks with constrained balance sheets they could lower the risks to asset quality and default.

Berger, Hasan and Zhou (2010) studied the performance of 88 Chinese banks between 1996 and 2006. Their analysis was based on concentration versus diversified activities of banks in four areas. The economies of diversification to these banks was based on profit premiums and cost discounts. The profit premium and cost discounts were the difference between profits and costs of actual banks and a hypothetical concentrated firm. The diversification possibilities were classified according to geography, loans, deposits and assets. The measures of diversification were regressed on bank specific factors of cost efficiency, performance, risk, size, ownership, and conglomerate affiliation. The findings suggested a negative impact of diversification on bank performance in all activity areas. They observed a declining profit premiums and augmented cost factors for more diversified banks. The diseconomies of diversification were low in foreign bank and conglomerates suggesting that such banks were able to mitigate some of the negative impact of diversification. These findings were interesting for emerging markets in general and China in particular that have a constrained policy on foreign ownership in domestic financial institutions.

Elsas et al (2010) investigated the impact of earnings diversification on the shareholders' wealth. Their sample constituted of 380 banks from nine developed economies for the years between 1996 and 2008. The earning diversification was measured using Herfindahl Hirschman index based on various streams of revenues. The firm specific factors included performance measures of ROA, ROE, spread, market based measures of cost of equity, market to book, beta and bank growth measures of vertical integration, equity growth, mergers and acquisition growth and organic growth. The results suggested that earnings diversification had a positive relation with bank profitability emanating from non interest businesses and cost efficiency. For the market based factors, they suggested that better bank performance leads to high bank valuations showing an indirect positive relationship between shareholders' wealth and revenue diversification resulting in conglomerate premium in banking sector. They noted that their results are in contradiction with the previous findings for two main reasons. Primarily, the positive relation between diversification and shareholder value is attributed to different measures of diversification that were used previously. 
Damankah, Anku-Tsede and Abubakar (2015) studied the income Diversification and Financial Stability of Banks in Ghana. The study considered income diversification in the Ghanaian banking sector by analyzing the relationship between non-interest income and profits of banks from the year 2002to 2011 and also considers the risk associated with bank income diversification. The study found that interest income remained the highest contributor to bank profits in Ghana. It was also found that revenue from non-interest sources play an augmenting role in times where there are short falls in interest revenue. This conclusion has implications for regulators interested in the stability of the banking sector, investors interested in the performance of individual banks or the entire banking/financial sector and bank borrowers who may depend on the health of specific banks for the stable provision of credit. Ismail (2015) studied income-diversification in banking sector of Pakistan: a 'Blessing' or 'Curse' Considering the importance of income diversification for developing financial markets, this study aims to fill the gap in existing literature of Pakistan by empirically exploring the relationship between income diversification and banking performance for the period of 20062013. The results of the study have shown positive impact of income diversification on performance of banks in Pakistan. The findings of the study are important for bankers to understand how income diversification affects the performance of banks. The findings are also helpful to the banks' management and regulators to understand the role of income diversification in value creation and risk-reduction for the stakeholders.

Alaaeddin (2017) studied noninterest income and financial performance at Jordanian banks. 13 banks in Jordan during the period 2000-2015 were. The impact of size of bank, loans, capital adequacy and overhead expenses on banks performance found to have a significant impact on banks performance. In more details, overhead expenses decrease bank performance, while capital adequacy, loans and size increase it. In addition, non-interest income increases equity capital adequacy and this in turn affects the profitability positively.

Sigve and Lars (2017) examined the effect of funding diversification on banks' performance a case study of the Norwegian banking market. The study sought to evaluate the effect of funding diversification on bank performance using annual data from 112 banks in Norway over the period 2004-2013. The findings suggested that increased funding diversification improved performance for banks in Norway. AIDEA, (2013) investigated the effect of revenue and geographic diversification on bank performance, also on a risk adjusted basis. Using an unbalanced panel dataset of 3,060 observations relative to Italian banks for the period 20062011, the core question is to analyse the effect of geographic and functional diversification across and within both interest and non-interest income and their effect on some principal performance measures. Furthermore in our study we analyse whether certain type of institutions are better able to reap the benefits of diversification analysing performance implications for different categories of banks and if the results have been affected by the financial crisis. The main results suggest that revenue and geographical diversification play a role in determining bank performance. The relative effects appear, however, to be different between mutual and not-mutual banks suggesting different business strategies for different banks.

Goetz et al. (2012) examines the impact of the geographic diversification of bank holding company assets across the United States on their market valuations. They find that increases in geographic diversity due to interstate bank deregulation reduced $\mathrm{BHC}$ valuations consistently with the view that an exogenous increase in complexity allows corporate insiders to extract larger private rents with adverse implications on firm value. Arasa, (2014) conducted a study on the effect of the diversification strategy on the performance of Kenya Commercial Bank group. Both primary and secondary data were collected by the researcher. Primary data was successfully collected from five senior managers of the bank, whereas secondary data was 
collected from the audited financial reports of Kenya Commercial Bank group limited. The study took the form of a case study of KCB group. Trend and content analysis were used to establish the effect of diversification on performance. The findings revealed that geographical diversification has a positive effect on the performance of KCB group. Some of the recommendations for further research proposed were that, the bank should explore more ways and forms of diversification in order to enhance its performance.

Celine et al, (2016) studied the benefits of geographic diversification within states and across states for bank risk and return for all U.S. bank holding companies over 1994 to 2008, and assess whether such benefits depend on bank size. For small banks, only intrastate diversification increases risk-adjusted returns and reduces default risk while for very large institutions only interstate expansions are beneficial but only in terms of default risk. In all cases the relationship was positive shaped indicating that at some point, the possible agency costs associated with banks getting wider and more geographically diversified outweigh the benefits. The results indicate that small banks and very large banks could still benefit from further geographic diversification. Mochabo (2017) studied the effect of bank diversification on the financial distress of commercial banks listed at the Nairobi securities exchange, Kenya. The study sought to determine the effect of bank diversification on financial distress of commercial banks listed in the Nairobi Securities Exchange. The specific objective of the study was to determine the effect of geographical and asset base diversification on the financial distress of the listed commercial banks in the NSE. Exploratory research design was used. The research targeted ten listed commercial banks in the NSE. This study used panel data of a ten years period (2006-2015) from the audited and published financial statements of commercial banks. Descriptive and inferential statistics was employed for data analysis. This study established that geographical diversification was positively and significantly correlated with financial distress. The study recommended that banks should adopt a moderate geographical strategy of diversification to enhance financial health of the banks.

Turkmen, and Yigit (2012) studied diversification in Banking and its Effect on Banks' Performance: Evidence from Turkey. The study sought to determine whether diversification via funding, sectoral and geographical credits helps banks. The study analysed on 40 banks' data. Financial performance was measured by Return on Assets (ROA) and Return on Equity (ROE). The study found that diversification improved ROA and ROE. The findings were confirmed to emanate from the fact that diversifying credit portfolios influence the risk level that banks take on. Losses in one sector or location can be compensated from the gain obtained from other sector or location etc. On the other hand, if the diversification level increases, it leads to rising of costs that are undertaken and diversification may not be associated with higher returns in every circumstances. It is important to make strategic decisions for a bank, in cases of risk and return preferences. Diversification on funding was also found to caution the financial performance through financing exposure and liquidity.

Ogada (2016) studied the effect of diversification on the financial performance of merged institutions. The purpose of the study was to assess the effect of diversification on the financial performance of merged institutions. The study adopted a mixed methodology research design. The study population included all the 51 merged financial service institutions in Kenya. Purposive sampling was used. Primary data was obtained from questionnaires and a secondary data collection template was also used. Diversification had no significant effect on financial performance of merged institutions. The study findings call for a re-assessment of the literature on diversification. Further research is necessary to study why sometimes the diversificationperformance relationship is positive, others negative, and often quadratic. Further research is needed to investigate whether diversification effects on performance depends on the industries considered. Mercieca et al. (2007) explored the economic impact of diversification on average 
profitability by calculating the effect of an increase in the non-interest share on a sample of 755 small European banks for the period 1997-2003. The analysis evidences that an increase in non-interest activities has two main effects, which are a direct impact from shifting into noninterest activities and, an indirect effect arising from changes in diversification. Moreover, a negative net effect for average profitability and a corresponding positive effect on volatility are detected. The results are robust with respect to several controls, suggesting that over the investigated period the higher volatility of net-interest income outweighs diversification benefits.

Rossi et al (2009) analysed the impact of diversification on firm specific characteristic of banking risks, costs, profit efficiency and capitalization on 96 Austrian commercial banks between 1997 and 2003. The study tested the relation of diversification with three basic hypotheses including classical diversification, bank monitoring and funding. They reported a positive relationship of diversification with firm profits and a negative relation between diversification and banking costs and risks. They also observed that increase in diversification lowers the funding requirements for banks. The study further provided some evidence, albeit weak, on management behavior and luck hypotheses. The results suggested that well managed banks are likely to achieve cost and profit efficiency through diversification and such firms are expected to warrant low provisions reducing overall realized risk of the bank. Lastly, the exogenous economic shocks, termed as bad luck hypothesis, are likely to lower bank performance even if they are otherwise diversified. Maina, (2013) conducted a study on the relationship between product diversification and financial performance of commercial banks in Kenya. This has been achieved through: establishing the level of income source diversification of commercial banks in Kenya and establish whether product diversification improves financial position of commercial banks. This was a census study of all registered 43 commercial banks in Kenya and relied heavily on documentary secondary data for 5 year study period (2008-2012). Herfindahl-Hirschman Index, Correlations and Regression analysis were mainly used and revealed on aggregate that all commercial banks in Kenya are diversified with large banks in lead while Islamic banks trail. Further, diversification level has a positive influence on financial performance of commercial banks in Kenyan. This study recommended that banks should extend their product mixes to increase profitability through combination of traditional intermediation activities and non interest activities.

Otieno and Moronge, (2014) investigated the influence of product diversification on the financial performance of selected commercial banks in Kenya. The study population was 40 top management, 200 middle level management and 360 junior staff working in 4 commercial banks in Kenya. The study used stratification sampling to collect data from the four selected banks. The study randomly sampled $10 \%$ of the junior staff. Random sampling was used to obtain a sample of the top management and middle level management respondents from the selected banks. Validity was ensured through discussion with the experts including supervisors and colleagues. Primary data was collected and analyzed using quantitative and qualitative techniques and then presented using narratives, tables and graphs. Secondary data was also obtained from books journals and commercial banks data base. Data collected was analyzed using SPSS (Statistical Package for Social Sciences) version 21. Descriptive statistics and inferential statistics such as multiple regression were used. This assisted in determining the level of influence the independent variables had on the dependent variable. The findings showed that that technology, information flow, new markets and innovativeness had effect on financial performance.

Kenyoru (2016) studied the effect of product diversification on financial performance of selected banks in Kericho Town. This study was carried out on Commercial Banks in Kericho town. The study targeted all the employees of the Commercial Banks. The findings indicated 
significant and positive relationship between the vertical product diversification and bank financial performance, horizontal product diversification strategy had positive and significant relationship with financial performance. The study recommended that the bank diversifies its products and especially focus on the untapped investments which accrue as a result of conglomerate diversification. Athanasoglou, et al. (2006) applied a dynamic panel data model to study financial performance of Greek banks over the period 1985-2001. The study found that the profitability of Greek banks is shaped by bank-specific factors and macroeconomic control variables, which are not under the direct control of bank management. Industry structure does not seem to significantly affect profitability.

Olweny \& Shipho (2011) studied the effects of banking sectoral factors on the profitability of commercial banks in Kenya. This study adopted an explanatory approach by using panel data research design to fulfil the above objectives. Annual financial statements of 38 Kenyan commercial banks from 2002 to 2008 were obtained from the CBK and Banking Survey 2009. The data was analyzed using multiple linear regressions method. The analysis showed that all the bank specific factors had a statistically significant impact on profitability, while none of the market factors had a significant impact. Alemu (2015) examined determinants of commercial banks profitability of eight banks in Ethiopia from for 10 years from 2002 -2013. The study used multiple linear regressions and the fixed effect regression model to analyze data. The study established that size of banks; capital adequacy and gross domestic product have a positive and statistically significant relationship with profitability of banks. The findings of the study also revealed that liquidity risk, operational efficiency, funding cost and banking sector development have a negative and statistically significant relation with profitability of banks.

Majok (2015) investigated performance of commercial banks in Kenya. The study used a descriptive research survey. The target population comprised all 43 commercial banks operating in Kenya as at December 2014. The secondary data was collected from the banks' consolidated financial statements as well as Central Bank of Kenya offices. The study found the financial performance of banks as measured by the returns on assets ratio was in constant fluctuation. Moraa (2014) conducted an analysis of profitability of Kenya's top six commercial banks: internal factor analysis used return on assets as a measure of profitability. The findings revealed that bank size, capital strength, ownership, operations expenses, diversification do significantly influence profitability of the top six commercial banks. The result suggests that the Kenyan Government should set policies that encourage commercial banks to raise their assets and capital base as this will enhance the performance of the sector. Nonetheless, the majority of researchers believe that capital increase has positive effects on the bank's profitability and improving the market value of its stock. Otieno and Moronge (2014) examined the financial performance of selected commercial banks in Kenya. The study used both secondary and primary data and analysed through descriptive statistics and inferential statistics including multiple regression. The findings were that that technology, information flow, new markets and innovativeness had effect on financial performance. The study recommended that though all banks were employing use of technology in rendering financial services in the country, they should ensure that those systems are of high and quality state ensuring that they are up to date. 


\section{Research Methodology}

This study adopted the descriptive research design since the study sought to establish the effect of financial diversification on financial performance of commercial banks in Kenya. The descriptive research design was chosen since it ensures complete description of the situation as it is, making sure that there is minimum bias in the collection of data and to reduce errors in interpreting the data to be collected. The study's population was all the 42 commercial banks in Kenya as at $31^{\text {st }}$ December 2017 (Central Bank of Kenya, 2017). The study adopted a census approach where all the 42 commercial banks in Kenya were studied. Therefore, no sampling was done since the population was considered manageable. The study used secondary data to achieve the objectives of the study. Secondary data comprised of financial performance measures which included return on assets, return on equity and liquidity; and independent variables measures which included income, product and geographical diversification. Secondary data was obtained from the banks financial statements for the last five years (20132017). Data was gathered using secondary data collection sheets. Data collected was scrutinized to ensure accuracy. Descriptive statistics was used in describing the data obtained. Trend analysis figures were used to assess the variability of dependent and independent variables over the study period. Inferential statistics obtained by conducting regression analysis were used to achieve the study objectives.

To determine the nature of the panel data and determine the best model for analysis, diagnostic test for heteroscedasticity was done using Wald Chi-square test, serial correlation was tested using Wooldridge Drukker test and to determine between random and fixed effects, Hausman test was used. The long run specifications were estimated using the fixed effects and random effects models while the short run model was estimated using system GMM estimator. Generalized method of moments (GMM) is a statistical method that combines observed economic data with the information in population moment conditions to produce estimates of the unknown parameters of this economic model (Mugenda \& Mugenda, 2008). To establish the reliability of the estimates a number of post estimation diagnostics was interpreted. The fixed and random effect model involved interpretation of the F statistic, interclass correlation (rho), within and between R-square, chow test statistics, LM test statistic and Hausman test. The short run GMM specification involved the interpretation of Hansen $\mathbf{J}$ statistic and the Arrelano and Bond autocorrelation tests. In order to establish the effect of financial diversification on financial performance of commercial banks, panel data regression was used. According to Cheng (2004) panel data usually gives the researcher a large number of data points, it therefore increases the freedom in one hand and decreases the collinearity on the other hand and thus the efficiency of econometric estimates was achieved or improved. Further, Cheng (2004) concluded that longitudinal data allows a researcher to analyze a number of important economic issues that can be addressed using cross sectional or time series data sets with ease.

\section{Research Findings}

For insights into the association between the dependent variable and independent variables focus was on the correlation analysis which was conducted to see the existence of multicollinearity. In addition, correlation analysis informs which variables should be dropped for having the same information (near perfect correlation). The section is organized as per the domains of financial performance measures involved in each objective. The correlations between Diversification components and return on assets is shown in Table 1. 
Table 1 Pairwise correlation between Diversification components and return on assets

\begin{tabular}{|c|c|c|c|c|c|}
\hline & & ROA & $\begin{array}{l}\text { Income Source } \\
\text { Diversification }\end{array}$ & $\begin{array}{l}\text { Geographical } \\
\text { Diversification }\end{array}$ & $\begin{array}{l}\text { Product } \\
\text { Diversification }\end{array}$ \\
\hline Income & Pearson & & & & \\
\hline Diversification & Correlation & $.337 * *$ & 1 & & \\
\hline & Sig. (2-tailed) & 0 & & & \\
\hline Geographical & Pearson & & & & \\
\hline Diversification & Correlation & $.248 * *$ & $.444 * *$ & 1 & \\
\hline & $\begin{array}{l}\text { Sig. (2-tailed) } \\
\text { Pearson }\end{array}$ & 0.000 & 0.000 & & \\
\hline Product Diversification & Correlation & $-.226^{* *}$ & -0.03 & -0.088 & 1 \\
\hline & Sig. (2-tailed) & 0.002 & 0.687 & 0.239 & \\
\hline & $\mathrm{N}$ & 202 & 202 & 202 & 202 \\
\hline
\end{tabular}

**. Correlation is significant at the 0.01 level (2-tailed).

As shown by Table 1 Income Source Diversification had a correlation coefficient of 0.337 and a p-value of 0, Geographical Diversification had a correlation coefficient of 0.248 and a pvalue of 0 while Product Diversification had a correlation coefficient of -0.226 and a p-value of 0.002. The positive correlation coefficients of Income Source Diversification and Geographical Diversification indicated that they had a positive impact on return on assets of the commercial banks while the negative coefficient of Product Diversification indicated it had a negative impact on return on assets. All the variables had p-values less than 0.05 and 0.01 showing that $95 \%$ and $99 \%$ confidence levels all the diversification components were significantly correlated with return on assets.

The correlations between Diversification components and return on equity is shown in Table 2.

Table 4. 1 Pairwise correlation between Diversification components and return on equity Return

on Income Source Geographical Product

Equity Diversification Diversification Diversification

\begin{tabular}{|c|c|c|c|c|c|}
\hline Income & Pearson & & & & \\
\hline \multirow[t]{2}{*}{ Diversification } & Correlation & $.384 * *$ & \multicolumn{3}{|l|}{1} \\
\hline & Sig. (2-tailed) & 0 & & & \\
\hline Geographical & Pearson & & & & \\
\hline \multirow[t]{2}{*}{ Diversification } & Correlation & $.268 * *$ & $.344 * *$ & 1 & -0.088 \\
\hline & $\begin{array}{l}\text { Sig. (2-tailed) } \\
\text { Pearson }\end{array}$ & 0.000 & 0.000 & & 0.239 \\
\hline \multirow[t]{3}{*}{ Product Diversification } & Correlation & $-.224 * *$ & -0.03 & -0.088 & 1 \\
\hline & Sig. (2-tailed) & 0.002 & 0.687 & 0.239 & \\
\hline & $\mathrm{N}$ & 202 & 202 & 202 & 202 \\
\hline
\end{tabular}

**. Correlation is significant at the 0.01 level (2-tailed).

As shown by Table 2, Income Source Diversification had a correlation coefficient of 0.384 and a p-value of 0, Geographical Diversification had a correlation coefficient of 0.268 and a pvalue of 0 while Product Diversification had a correlation coefficient of -0.224 and a p-value of 0.002. The positive correlation coefficients of Income Source Diversification and Geographical Diversification indicated that they had a positive impact on return on equity of the commercial banks while the negative coefficient of Product Diversification indicated it had a negative impact on return on equity. All the variables had p-values less than 0.05 and 0.01 
showing that $95 \%$ and $99 \%$ confidence levels all the diversification components were significantly correlated with return on equity. In order to establish the effect of financial diversification on financial performance of commercial banks, panel data regression was used. Panel data usually gives the researcher a large number of data points and it therefore increases the freedom in one hand and decreases the collinearity on the other hand and thus the efficiency of econometric estimates was achieved. The study presents the findings as follows; each long run model is presented separately and its post-estimation diagnostics discussed to establish the reliability of the findings.

To determine the relationship that exists between the dependent and independent variables, stepwise regression analysis was computed. Regression analysis was used to evaluate the contribution of each independent variable in explaining the dependent variable, when the other variables are controlled; the R Square value was obtained for each variable. The results in Table 3 shows that the Diversification Components studied explain $13.3 \%$ of the variations in return on assets $\left(\mathrm{R}^{2}=0.133\right)$. This implies that $86.7 \%$ of the variation in the return on assets at the commercial banks is explained by factors other than those investigated.

Table 3 Model Summary with ROA as dependent variable

\begin{tabular}{llll}
\hline $\mathrm{R}$ & $\mathrm{R}$ Square & Adjusted R Square & $\begin{array}{l}\text { Std. Error of the } \\
\text { Estimate }\end{array}$ \\
\hline $.365 \mathrm{a}$ & 0.133 & 0.12 & 0.03713 \\
\hline $\begin{array}{l}\text { a. Predictors: } \\
\text { Geographical Diversification } \\
\text { b. Dependent Variable: } \text { Return on Assets }\end{array}$ & &
\end{tabular}

The study further undertook ANOVA analysis to establish the validity and effectiveness of the model in explaining the relationship between the study variables. The model in Table 4 was found to be valid $\left(\mathrm{F}_{(3,196)}=10.054, P<.001\right)$ as shown by Table 4 meaning that the independent variables are a good predictor of variations in return on assets.

Table 4 Analysis of Variance with ROA as dependent variable

\begin{tabular}{llllll}
\hline & Sum & of & Mean & & \\
& Squares & Df & Square & F & Sig. \\
\hline Regression & 0.042 & 3 & 0.014 & 10.054 & $.000 \mathrm{a}$ \\
Residual & 0.27 & 196 & 0.001 & & \\
Total & 0.312 & 199 & & & \\
\hline $\begin{array}{l}\text { a. Predictors: } \\
\text { Geographical Diversification }\end{array}$ & (Constant), Product & Diversification , Income & Source & Diversification , \\
b. Dependent Variable: Return on Assets & & & &
\end{tabular}

The model coefficients obtained indicated that Income Source Diversification had a coefficient of 0.254, Geographical Diversification had a coefficient of -1.4905 while Product Diversification had a coefficient of -0.003 as shown by Table 5. This shows that only Product Diversification influenced the return on assets of the commercial banks positively. Additionally, all the variables except Product Diversification were established to be significant as they have a p-value less than $5 \%(P<0.05)$ meaning that, when all variables in this study are combined they are significant in explaining the variations in the return on assets. 
Table 5 Model Coefficients with ROA as dependent variable

\begin{tabular}{llllll}
\hline & \multicolumn{3}{l}{ Unstandardized Coefficients } & \multicolumn{3}{c}{ Standardized Coefficients } \\
& $\mathrm{B}$ & Std. Error & Beta & $\mathrm{t}$ & Sig. \\
\hline (Constant) & 0.014 & 0.004 & & 4.067 & 0.000 \\
Income Source Diversification & 0.254 & 0.072 & 0.351 & 3.533 & 0.001 \\
Geographical Diversification & -1.4905 & 0 & -0.017 & -0.171 & 0.864 \\
Product Diversification & -0.003 & 0.002 & -0.133 & -2.001 & 0.047 \\
\hline
\end{tabular}

a. Dependent Variable: Return on Assets

To determine the relationship that exists between the dependent and independent variables, stepwise regression analysis was computed. The results in Table 4.17 shows that the Diversification Components studied explain $18.7 \%$ of the variations in return on equity $\left(\mathrm{R}^{2}=0.187\right)$. This implies that $81.3 \%$ of the variation in the return on equity at the commercial banks is explained by factors other than those investigated.

Table 6 Model Summary with ROE as dependent variable

\begin{tabular}{llll}
\hline $\mathrm{R}$ & $\mathrm{R}$ Square & Adjusted R Square & $\begin{array}{l}\text { Std. Error of the } \\
\text { Estimate }\end{array}$ \\
\hline $.432 \mathrm{a}$ & 0.187 & 0.174 & 0.19624 \\
\hline $\begin{array}{l}\text { a. Predictors: } \\
\text { Geographical Diversification } \\
\text { b. Dependent Variable: Return on Equity }\end{array}$ & &
\end{tabular}

The study further undertook ANOVA analysis to establish the validity and effectiveness of the model in explaining the relationship between the study variables. The model in Table 6 was found to be valid $\left(\mathrm{F}_{(3,196)}=14.998, P<.001\right)$ as shown by Table 4.18 meaning that the independent variables are a good predictor of variations in return on equity.

Table 7 Analysis of Variance with ROE as dependent variable

\begin{tabular}{|c|c|c|c|c|c|}
\hline & $\begin{array}{l}\text { Sum } \\
\text { Squares }\end{array}$ & Df & Mean Square & $\mathrm{F}$ & Sig. \\
\hline Regression & 1.733 & 3 & 0.578 & 14.998 & $.000 \mathrm{a}$ \\
\hline Residual & 7.548 & 196 & 0.039 & & \\
\hline Total & 9.28 & 199 & & & \\
\hline
\end{tabular}

The model coefficients obtained indicated that Income Source Diversification had a coefficient of 1.686, Geographical Diversification had a coefficient of 0.000 while Product Diversification had a coefficient of -0.024 as shown by Table 8 . This shows that only Product Diversification influenced the return on equity of the commercial banks negatively.

Table 8 Model Coefficients with ROE as dependent variable

\begin{tabular}{|c|c|c|c|c|c|}
\hline & \multicolumn{5}{|c|}{ Unstandardized } \\
\hline & B & Std. Error & Beta & $\mathrm{t}$ & Sig. \\
\hline (Constant) & 0.097 & 0.019 & & 5.236 & 0.000 \\
\hline Income & & & & & \\
\hline $\begin{array}{l}\text { Diversification } \\
\text { Geographical }\end{array}$ & 1.686 & 0.379 & 0.428 & 4.442 & 0.000 \\
\hline Diversification & 0.000 & 0 & -0.059 & -0.608 & 0.544 \\
\hline Product Diversification & -0.024 & 0.008 & -0.192 & -2.976 & 0.003 \\
\hline
\end{tabular}




\section{a. Dependent Variable: Return on Equity}

Additionally, all the variables except Geographical Diversification were established to be significant as they have a $\mathrm{p}$-value less than $5 \%(\mathrm{P}<0.05)$ meaning that, when all variables in this study are combined they are significant in explaining the variations in the return on equity.

\section{Conclusions}

Income diversification had a positive and significant effect on the financial performance of the commercial banks in Kenya. Hence increase in income diversification will translate in improved financial performance in the commercial banks. The study thus concludes that income diversification is essential in promoting not only the financial security of the commercial banks but also improving the overall financial performance. Geographical diversification had a positive and significant correlation with the financial performance of the commercial banks in Kenya. The study therefore concludes that geographical diversification is essential in enhancing the financial performance of the commercial banks through increasing widespread coverage of the organizations hence higher returns. To improve the financial performance of the commercial banks, the banks should ensure that they are fully diversified in all geographical regions.

Product diversification had a negative but significant effect on the financial performance of the commercial banks in Kenya. The study thus makes the conclusion that product diversification is a significant contributor to how the commercial banks performed. Therefore, more diversification of the products offered by the commercial banks is concluded to lead to better financial performance. Diversification components studied namely product diversification, geographical diversification and income diversification have a significant positive relationship with the financial performance of the commercial banks in Kenya. The study thus concludes that the current financial performance of the commercial banks in Kenya is largely accounted for by the effectiveness of the diversification strategies that have been implemented. It is further concluded that increased formulation and implementation of additional diversification strategies will result in significant improvement in the financial performance of the commercial banks.

\section{Recommendations}

The study found out that diversification components studied namely product diversification, geographical diversification and income diversification have a positive effect on the financial performance of the commercial banks in Kenya. It is therefore recommended that all the commercial banks in Kenya to establish appropriate frameworks for the implementation of diversification strategies. The study also recommends that managers at the commercial banks to make formulation and implementation of diversifications as a key organizational priority. They should therefore not only define the diversifications methods but also constantly monitor and evaluate their efficiency. The study also recommends that before the adoption of any particular diversification, the management in the commercial banks to first determine the suitability of that particular diversification strategies based on the organization structure, culture and policies and the overall intended outcomes. This will ensure that the diversification strategies put in place are able to meet and surpass their set objectives and targets. It also recommended that the banks should also exploit additional ways of improving the efficiency of operations so as to improve their financial performance and protect the shareholders capital.

The study recommends that the government and other regulatory bodies to create favourable policies on the implementation of diversifications in commercial banks. This will ensure that there is effectiveness, efficiency as well as consistency in the use and adoption of diversifications by not only the banks but also other organizations in different sectors. This will 
also facilitate mitigation of challenges associated in the implementation process of these strategies promoting their overall effectiveness and end results accrued from them. The study further recommends that the Kenyan Government and other policy makers to ensure that the macro environment are stable and constant so as to minimize occurrences of unforeseeable risks from the external environment that might hinder the effectiveness of these strategies.

\section{References}

Adamu, N., Zubairu, I., Yahya, I., and Makarfi, I., (2011). Evaluating the Impact of Product Diversification on Financial Performance of Selected Nigerian Construction Firms. Journal of Construction in Developing Countries, 16(2), 91-114

Afzal, A., \& Mirza, N., (2012). Size, Diversification and Risk: Preliminary Evidence from Commercial Banks in Pakistan. Pak. J. Commer. Soc. Sci., 6 (2), 282-296

AIDEA, (2013). Effect of revenue and geographic diversification on bank performance. Paper to be presented at the AIDEA Bicentenary Conference.

Alaaeddin, A., (2017). Noninterest Income and Financial Performance at Jordanian Banks. International Journal of Financial Research, 8, 1, 166-171

Amato, L. and Wilder, R. P. (1985). The Effects of Firm Size on Profit Rates in U. S. Manufacturing, Southern Economic Journal, Vol. 52, No. 1, pp. 181 - 190

Arasa, S., (2014). Effect of the diversification strategy on the performance of Kenya Commercial Bank group. Unpublished MBA Project, University of Nairobi.

Athanasoglou, P., Delis, M., \& Staikouras, C. (2006). Determinants of bank profitability in the South Eastern European region.

Berger, A., Hasan, I. and Zhou, M. (2010). The effects of focus versus diversification on bank performance: Evidence from Chinese Banks. Journal of Banking and Finance, 34, 1417-1435

Brealey, R.A., \& Myers, C.S. (2003). Principles of Corporate Finance, (7th edition), McGraw-Hill Companies

Céline, M., Donald P., Katherine, S., \& Amine, T.,(2016). The Benefits and Costs of Geographic Diversification in Banking. Journal of International Money and Finance, Elsevier, 69, pp.287317.

Central Bank of Kenya (2016). Banking Supervision Annual Report 2016; Nairobi: Central Bank of Kenya

Central Bank of Kenya (2017). Directory of Licenced Commercial Banks, Mortgage Finance Institutions And Authorised Non-Operating Holding Companies. Accessed on May 30, 2018 from at https://www.centralbank.go.ke/wp-content/uploads/2017/05/Directory-of-LicencedCommercial-Banks-Mortgage-Finance-Institutions-and-NOHCs.pdf

Central Bank of Kenya (2018). The Impact of Interest Rate Capping on the Kenyan Economy. Nairobi: Central Bank of Kenya

Cheng, H. (2004). Analysis of panel data. Computers \& Mathematics with Applications. The Press Syndicate of the University of Cambridge.

Cui, L. (2003). Empirical study of capital structure on agency costs in Chinese listed firms. Nature and Science, 1(1), 12-20. Google Scholar

Daily, C. M., Dalton, D. R., \& Rajagopalan, N. (2003). Governance through ownership: Centuries of practice, decades of research. Academy of Management Journal, 46(2), 151-158.

Damankah, B. S., Anku-Tsede, O., \& Abubakar, M., (2015). Income Diversification and Financial Stability of Banks in Ghana. International Journal of Business and Social Science, 6, 6, 177184

De Jonghe, O. (2010) Back to the basics in banking? A microanalysis of banking system stability, Journal of Financial Intermediation, 19, 387-417.

Eisenhardt, K. M. (1989). Agency theory: An assessment and review. Academy of Management Review, $14(1), 57-74$

Eiteman, D. K., (2016). Multinational business finance. Pearson Higher Ed.

Elsas, R., Hackethal, A. and Holzhauser, M. (2010). The Anatomy of Bank Diversification. Journal of Banking and Finance, 34, 1274-1287 
Gambacorta, L., Scatigna, M., \& Yang, J. (2014). Diversification and bank profitability: a nonlinear approach. Applied Economics Letters, 21(6), 438-441.

Goetz, M., Laeven, L., Ross, L., (2012). The Valuation Effects of Geographic Diversification: Evidence from U.S. Banks. IMF Working Paper, WP/12/50.

Gray, M. A.. (2003). Portfolios and assessment of competence: a review of the literature. Journal of advanced nursing, 41(3), 283-294.

Ismail, A., (2015). Income-diversification in banking sector of Pakistan: a 'Blessing' or 'Curse'? The Journal of Commerce, 7, 1, 11-22

Jensen, M.C., and W.H. Meckling, (1976), Theory of the firm: Managerial behaviour, agency costs, and ownership structure, Journal of Financial Economics 3, 305-360.

Jongeneel, O.C.W. (2011). Bancassurance: Stale of Staunch? A Pan- European country analysis. Unpublished Msc. Economics \& Business Thesis, Erasmus University Rotterdam

Kenyoru, D., (2016). Effect of Product Diversification on Financial Performance of Selected Banks in Kericho Town. European Journal of Business and Management. 8,.22, 126-134

Kipleting, M, (2016). Effect of investment Diversification on the Financial Performance of Commercial Banks in Kenya. IOSR Journal of Business and Management, 18, 11. PP 102-115

Klein, P. and Saidenberg, M. (2010) Organisational structure and the diversification discount: evidence from commercial banking, Journal of Industrial Economics,58, 127-55

Lepetit, L., Nys, E., Rous, P. and Tarazi, A. (2008). Bank Income Structure and Risk: An Empirical Analysis of European Banks. Journal of Banking and Finance, 32, 1452-1467

Luo, Y. (2009), Product Diversification in International Joint Ventures: Performance Implications in an Emerging Market, Strategic Management Journal, 23 No. 1, pp. 1-20.

Maina, W., (2013). Product diversification and financial performance of commercial banks in Kenya. Unpublished MBA Project, University of Nairobi.

Majok, (2015). Effects of Exchange Rate Fluctuations on Financial Performance of Commercial Banks in Kenya. Unpublished MBA Project, University Of Nairobi.

Majok, E. (2015). Effects of exchange rate fluctuations on financial performance of commercial banks in Kenya. Universitas of Nairobi.

Makau, M., and Jagongo, A., (2018). The Impact of Portfolio Diversification on Financial Performance of Investment Firms Listed In Nairobi Securities Exchange, Kenya: Empirical Review. International Journal of Management and Commerce Innovations. 5, 2, 177-187

Makokha, A., Namusonge, G., and Sakwa, M., (2016). Effect of Portfolio Diversification on Commercial Banks Financial Performance in Kenya. European Journal of Business Management, 5, 9, PP-05-08

Makokha, A., Namusonge, G., and Sakwa, M., (2016). Effect of Portfolio Diversification on Commercial Banks Financial Performance in Kenya. European Journal of Business Management, 5, 9, PP-05-08

Markowitz, H. (1952). Portfolio Selection. The Journal of Finance, 7 (1), 77-91.

McKnight, P. J., Weir, C. (2009). Agency costs, corporate governance mechanisms and ownership structure in large UK publicly quoted companies: A panel data analysis. The Quarterly Review of Economics and Finance, 49(2), 139-158.

Mercieca, S., Schaeck, K., Wolfe, S., (2007). Small European banks: Benefits from diversification? Journal of Banking and Finance 31, 1975-1998.

Mishkin, F., Matthews, K., \& Giuliodori, M. (2013). The Economics of Money, Banking and Financial Markets (European edition). Harlow: Pearson Education LTD

Mochabo, I., (2017). Effect of Bank Diversification on the Financial Distress of Commercial Banks Listed at the Nairobi Securities Exchange, Kenya. International Journal of Scientific Research and Management (IJSRM), 5, 11, 7329-7343

Moraa, S., (2014). The Analysis of Profitability of Kenya`s Top Six Commercial Banks: Internal Factor Analysis. Research Journal of Finance and Accounting, 2, 8, PP-124-133

Mugenda, A., \& Mugenda, O. (2008). Research Methods: Quantitative and Qualitative Approaches. Nairobi: Africa Centre for Technology Studies (ACTS).

Ogada, A., (2016). Effect of Diversification on the Financial Performance of Merged Institutions. American Journal of Finance, 1, 2, PP 92-107 
Otieno, O. (2014). A \& Moronge, M.(2014). Influence of Product Diversification on the Financial Performance of Selected Commercial Banks in Kenya. European Journal of Business Management, 1(11), 336-341.

Otieno, O. A \& Moronge, M. (2014). Influence of Product Diversification on the Financial Performance of Selected Commercial Banks in Kenya. European Journal of Business Management, 1 (11), 336-341.

Pervan, M., and Josipa, V., (2012). Influence Of Firm Size On Its Business Success. Croatian Operational Research Review (CRORR), Vol. 3, pp 213-223

Republic of Kenya (2008), Kenya VISION 2030. Nairobi: Government Printer, Nairobi

Saoussen, G., \& Plihon, D., (2011). Revenue diversification in emerging market banks: implications for financial performance. Journal of Finance, 2, 4, 22-29

Sigve, A., \& Lars, A., (2017). The effect of industrial diversification on banks' performance A case study of the Norwegian banking market. Norway: Centre for Applied Research at $\mathrm{NHH}$

Stiroh, K. (2004) Diversification in banking: is noninterest income the answer?, Journal of Money, Credit and Banking, 36, 853-82.

Stiroh, K. (2004). Diversification in banking: is non-interest income the answer. Journal of Money, Credit and Banking, 36 853-82.

Tsuma, M., and Gichinga, L., (2016). Factors Influencing Financial Performance of Commercial Banks in Kenya- A Case Study of National Bank of Kenya Coast Region. The International Journal of Business \& Management, 4, 4, pp 62-79

Turkmen, S., \& Yigit, I., (2012). Diversification in Banking and its Effect on Banks' Performance: Evidence from Turkey. American International Journal of Contemporary Research. 2 , 12, 111-119

Winton, A. (1999). Don't Put All Your Eggs in One Basket? Diversification and Specialization in Lending, 00 (16). Working papers: the Wharton Financial Institutions Center

This is an open-access article published and distributed under the terms and conditions of the $(\mathrm{cc}) \mathrm{EY}$ Creative Commons Attribution 4.0 International License of United States unless otherwise stated. Access, citation and distribution of this article is allowed with full recognition of the authors and the source.

Authors seeking to publish with an International Peer Reviewed Journal should consider https://www.ijcab.org/ by writing to the Editor at editor@ijcab.org. The articles must be quality and meet originality test. 